
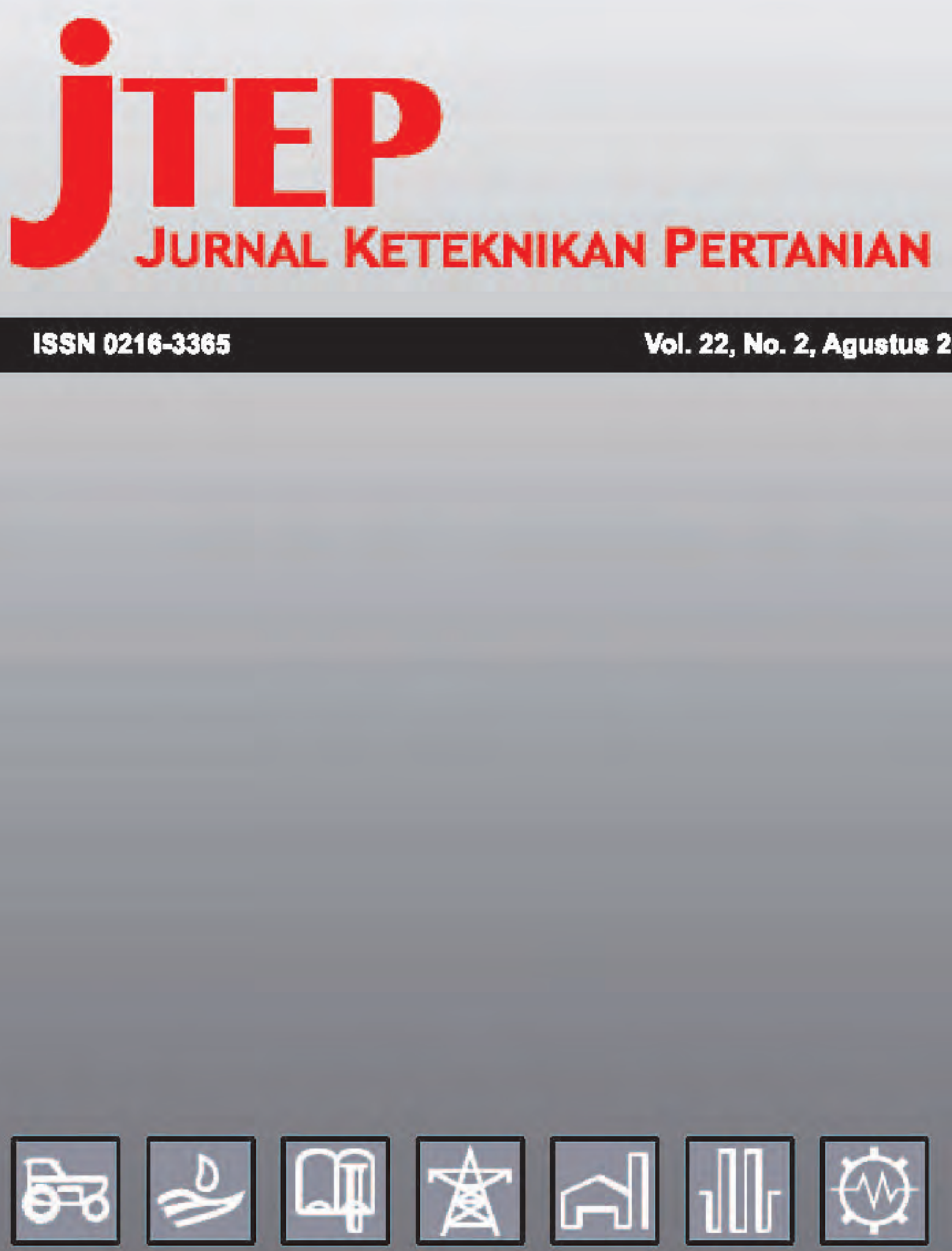

\title{
Publlkasl Resml
}

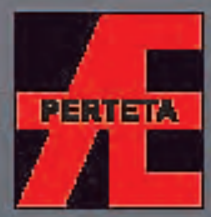

Perhimpunan Telknik Pertanian Indonesia (Indonesian Society of Agricultural Enginesring) bekerjasama dengan

Departemen Teknilk Pertanian - FATETA Institut Pertanian Bogor 


\section{jtep JuRnal Keteknikan Pertanian}

Vol.22, No.2, Agustus 2008

Jurnal Keteknikan Pertanian merupakan publikasi resmi Perhimpunan Teknik Pertanian Indonesia (PERTETA) yang didirikan 10 Agustus 1968 di Bogor, berkiprah dalam pengembangan ilmu keteknikan untuk pertanian tropika dan lingkungan hayati. Jurnal ini diterbitkan tiga kali setahun, namun untul meningkatkan kualitas jurnal maka mulai edisi April 2008 diterbitkan dua kali setahun. Penulis makalah tidak dibatasi pada anggota PERTETA tetapi terbuka bagi masyarakat umum. Lingkup makalah, antara lain: teknik sumberdaya lahan dan air, alat dan mesin budidaya, lingkungan dan bangunan, energi alternatif dan elektrifikasi, ergonomika dan elektronika, teknik pengolahan pangan dan hasil pertanian, manajemen dan sistem informasi. Makalah dikelompokkan dalam invited paper yang menyajikan isu aktual nasional dan internasional, review perkembangan penelitian, atau penerpan ilmu dan teknologi, technical paper hasil penelitian, penerapan, atau diseminasi, serta research methodology berkaitan pengembangan modul, metode, prosedur, program aplikasi, dan lain sebagainya. Pengiriman makalah harus mengikuti panduan penulisan yang tertera pada halaman akhir atau menghubungi redaksi via telpon, faksimili atau e-mail. Makalah dapat dikirimkan langsung atau via pos dengan menyertakan hard- dan soft-softcopy, atau e-mail. Penulis tidak dikenai biaya penerbitan, akan tetapi untuk memperoleh satu eksemplar dan 10 re-prints dikenai biaya sebesar Rp 50.000. Harga langganan Rp 70.000 per volume ( 2 nomor), harga satuan Rp 40.000 per nomor. Pemesanan dapat dilakukan melalui e-mail, pos atau langsung ke sekretariat. Formulir pemesanan terdapat pada halaman akhir.

\section{Penanggungjawab:}

Ketua Perhimpunan Teknik Pertanian Indonesia

Ketua Departemen Teknik Pertanian, Fakultas Teknologi Pertanian, IPB

\section{Dewan Redaksi: \\ Ketua : Asep Sapei \\ Anggota : Kudang B. Seminar \\ Daniel Saputra \\ Bambang Purwantana \\ Y. Aris Purwanto}

\section{Redaksi Pelaksana:}

$$
\begin{array}{ll}
\text { Ketua } & \text { : Rokhani Hasbullah } \\
\text { Sekretaris } & : \text { Satyanto K. Saptomo } \\
\text { Bendahara } & : \text { Emmy Darmawati } \\
\text { Anggota } & : \text { Usman Ahmad } \\
& \text { I Wayan Astika } \\
& \text { M. Faiz Syuaib } \\
& \text { Ahmad Mulyawatullah }
\end{array}
$$

Penerbit:

Perhimpunan Teknik Pertanian Indonesia (PERTETA) bekerjasama dengan

Departemen Teknik Pertanian, IPB Bogor

Alamat:

Jurnal Keteknikan Pertanian, Departemen Teknik Pertanian, Fakultas Teknologi Pertanian,

Kampus IPB Darmaga, Bogor 16680. Telp. 0251-8624691, Fax 0251-8623026,

E-mail: jtep@ipb.ac.id atau jurnaltep@yahoo.com. Website: ipb.ac.id/ jtep.

\section{Rekening:}

BRI, KCP-IPB, No.0595-01-003461-50-9 a/n: Jurnal Keteknikan Pertanian

Percetakan:

PT. Binakerta Adiputra, Jakarta 


\section{Ucapan Terima Kasih}

Redaksi Jurnal Keteknikan Pertanian mengucapkan terima kasih kepada para Mitra Bestari yang telah menelaah (mereview) naskah pada penerbitan Vol. 22 No. 2 Agustus 2008. Ucapan terima kasih disampaikan kepada Prof.Dr.Ir. Sukmono, MS (Fakultas Pertanian Sumatera Utara), Dr.Ir. Agung Hendriadi (BPP Mekanisme Pertanian Serpong), Dr. Ir. Bambang Dwi Argo, DEA (Departemen Teknik Pertanian, Universitas Brawijaya Malang), Dr.Ir. Rokhani Hasbullah, M.Si (Departemen Teknik Pertanian IPB), Dr.Ir. Usman Ahmad, M.Agr (Departemen Teknik Pertanian IPB), Dr.Ir. Leopold Oscar Nelwan, M.Si (Departemen Teknik Pertanian IPB), Dr.Ir. Sutrisno, M.Agr (Departemen Teknik Pertanian IPB), Dr.Ir. Y. Aris Purwanto, M.Sc (Departemen Teknik Pertanian IPB), Dr.Ir. Ridwan Rachmat, M.Agr (Balai Besar Penelitian dan Pengembangan Pasca Panen Pertanian), Dr.Ir. Bambang Purwantana, M.Agr (Departemen Teknik Pertanian UGM), Dr.Ir.Desrial, M.Eng (Departemen Teknik Pertanian IPB), Dr.Ir. Abdul Rozaq (Departemen Teknik Pertanian UGM), Prof.Dr.Ir. Asep Sapei, MS (Departemen Teknik Pertanian IPB), Dr.Ir. Ridwan Tahrir (Balai Besar Penelitian dan Pengembangan Pasca Panen Pertanian). 
Review

\title{
Getaran Akibat Gangguan Secara Alami
}

\author{
Self Excited Vibration
}

\author{
Soeharsono' dan Radite P. A. Setiawan ${ }^{2}$
}

\begin{abstract}
This paper discusses the phenomenon of self-excited vibration in some physical model including its applications in some different engineering field. The referred physical model include the impact damper and its application for damping the vibration of shear building, chatter phenomenon on machine tools, ride comfort on agricultural machinery and stick-slip phenomenon and its benefit on vibration subsoiler. It is intended that this paper could provide a global overview on phenomenon of self-excited vibration.
\end{abstract}

Keywords: self-excited, vibration, stick-slip, subsoile

Diterima: 03 Januari 2008; Disetuju: $12 \mathrm{Mol} 2008$

\section{Pendahuluan}

Parameter getar yang berpengaruh terhadap getaran struktur dinyatakan dalam inersia (massa dan kelembaman), elastisitas dan peredam. Inertia dan elastisitas merupakan potensi dari struktur untuk bergetar sedangkan peredam merupakan potensi guna meredam getaran stuktur.

Berdasarkan gangguan nya, getaran dibedakan dalam getaran bebas, getaran paksa dan self excited vibration. Getaran bebas terjadi bila struktur diberi simpangan awal atau kecepatan awal, dalam hal demikian struktur akan bergetar secara harmonis dengan frekuensi yang sesuai dengan frekuensi pribadi nya. Getaran paksa terjadi bila gangguan nya berupa gaya luar atau berupa gerakan rangka pendukung (support motion). Pada getaran paksa, struktur akan bergetar dengan frekuensi yang sesuai dengan frekuensi gangguan nya sedangkan besar amplitude getar nya tergantung pada frekuensi gangguan. Bila frekuensi gangguan nya berdekatan dengan frekuensi pribadi struktur, maka terjadi phenomena resonansi dan struktur akan bergetar hebat.

Bila gangguan nya berupa iteraksi antara gerakan struktur dengan lingkungan gerak nya, maka getaran tersebut dinamakan self excited vibration (SEV). Hal yang unik dari getaran ini adalah gangguan tersebut selalu tidak linier dan merupakan fungsi dari simpangan, kecepatan dan percepatan dari massa getar. Oleh karena itu tidak ada solusi yang sifatnya khusus dari getaran jenis ini bahkan pada beberapa kasus solusi eksperimental memberikan jawab yang mendekati kebenaran.
Pada tulisan ini akan dilakukan review dari artikel yang memuat tentang self excited vibration, aplikasi dan solusi yang ditawarkan. Pembahasan meliputi kasus impact damper beserta aplikasi nya pada shear building baik untuk kasus getaran bebas maupun getaran paksa, self excited vibration pada mesin perkakas (chatter) dan ketidak-nyamanan operator dalam mengoperasikan agricultural machinery akibat self excited vibration. Pada bagian akhir dari tulisan ini akan dibahas tentang phenomena stick-slip dan aplikasi nya pada mesin-mesin pertanian.

Phenomena Impact damper telah ditulis oleh Asfar et al (2005) dengan tujuan untuk mempelajari pengaruh dari impact viscous damper terhadap peredaman sistem getar satu derajad kebebasan. Model getar ditunjukkan pada Gambar 1 dengan parameter getar berupa impact mass $\mathrm{m}$, impact clearance $\Delta$, massa getar $M$, kekakuan pegas $K$, koefisien peredaman $\mathrm{C}$ serta koefisien peredaman negative $\mu$ dan $\alpha$.

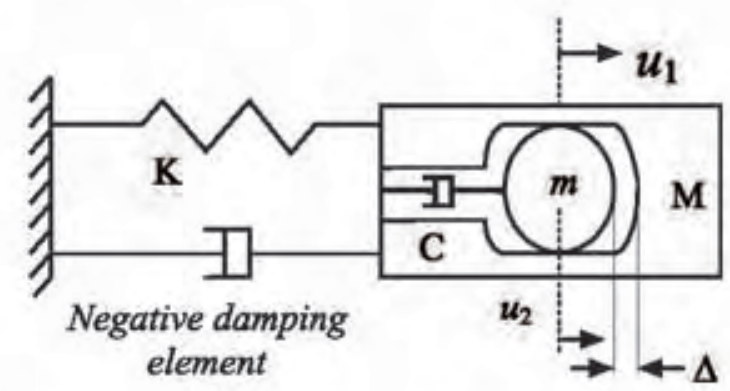

Gambar 1 Self-excited system dengan impact viscous dampar

\footnotetext{
${ }^{1}$ Fakultas Teknologi Industri, Universitas Trisakti, Jakarta 11440, mahasiswa Pasca Sarjana TEP IPB, Kampus IPB Dramaga Bogor 16680

2 Departemen Teknik Pertanian, Fakultas Teknologi Pertanian, Kampus IPB Dramaga Bogor 16680.
} 
Tabel 1 Waktu peredamen (atapsed thme f) untuk $\varepsilon=0.1$ den $\gamma=1 / 3$

\begin{tabular}{|c|c|c|c|}
\hline Macs ratio $\beta$ & Clesurence & $\begin{array}{c}\text { Demping } C \\
\text { ratto } \delta\end{array}$ & $\begin{array}{c}\text { Elepoed } \\
\text { time t }\end{array}$ \\
\hline $\begin{array}{l}0.2 \\
0.25 \\
0.3 \\
0.3 \\
0.4 \\
0.4\end{array}$ & $\begin{array}{c}\text { any value } \\
0.5-1.0 \\
0.3-0.4 \\
0.4-1.0 \\
0.25-0.35 \\
0.35-1.0\end{array}$ & $\begin{array}{c}\text { any vehue } \\
20-25 \\
30-40 \\
20-40 \\
30-80 \\
30-80\end{array}$ & $\begin{array}{c}\infty \\
400-300 \\
275-150 \\
150-280 \\
170-100 \\
100-300\end{array}$ \\
\hline
\end{tabular}

Untuk memudahkan simulagi numerik, makg Asfar mongubah parameter gotarnye dalam bentuk parameter tanpa dlmenas yaltu :

$$
\begin{aligned}
& \varepsilon=\mu N(\mathrm{KM}), \quad \gamma=\mathrm{CN}(\mathrm{KM}), \quad \beta=\mathrm{mM}, \\
& \mathrm{u}=\mathrm{u}^{*} \mathrm{~h}_{0}, \quad \omega_{0}=\sqrt{\mathrm{K} M}
\end{aligned}
$$

Dimana u'adalah panjang karakteriatk dan dp pllh sedemikjan rupa sehingga :

$$
a u_{0} k=M B
$$

Dalem soluti numerik nya, Asfer memilih parameter utama yang berpenganuh tentadap waktu peredemen (elepsed $t m e$ ) t yaltu mass ratto $\beta$. chearence ratio o peredem viscous pade masta peredam $\mathrm{C}$ dan faktor ketidak-Ilnloran $\varepsilon$, gedangkan nllal $\gamma$ dlbugt kongtan sebesar 1/3. Untuk $\varepsilon>0.1$, aigtem tidak akan teredam kecuali bila nilai moss ratio $\beta$ dlbuat besar dan sletem inl menjadl tidak efletf (Gember 2)

Hesil-he:gl jugg menunjukkan bahwa gistem tidak pemah teredam blla harpa derl mase ratto 8 leblh kecll darl 0.25 (Tabel 1). Secara umum potensl peredaman terjadi pada harga mass ratio $\beta$ dan cloarance ratto d yang semakdn beser Astar Juga melaporkan bahwa untuk besar harga $C$ yang melebihi angks optimum nya, sistem menjadi kontrzproduktt bahkan d abes herpa tertentu massa inpert damper menyahu dengan massa getar sehingga tidak torjadi phenomene peredeman.
Studi ekeperimentel tonteng inpect vilondion absorber yang dlpasang pada shos buldihng tolah dllakukan oleh Ekwaro ot al. (2001) dan Y. U et of. (2006) Tujuan dari kedua mya adalah mempelajari pengaruh impact vibration absorber terhadap peredemen getaran pade strukt shear budtolfing balk untuk kasus getaran bebere maupun untuk keasus getaran paksa.

Skema peralatan eksperimental Ekwaro dihunjukkan pade Gambar 3a berupa model shear bulloling satu derajad kebobasan dengen massa impact berupa massa ayun me. Massa getar mi dipasang pada base melalui empat buah batang kantllover dan frokutenst pribadl derl massa poter dl set pada $9 \mathrm{~Hz}$. Getaran bebas dldapat dengan memberi simpangan awal pada masse getar sedangken potaran pakse dllakukan dengen memberlkan gangguan pada basa berupa fungsi hamonis

Bkeme peralatan elcsperimentel Y. U dltun,ulkcen pada Cambar 3.b berupa model shear bullding tiga derajad kabebagan dengan gerakan messa impact my dilbuet llnier. Freklenel elaml derl shour buffelting berturut-tunut begar mya adalah $f_{1}=1.77 \mathrm{~Hz} f_{2}=5.22$ $\mathrm{Hz}$ dan $\mathrm{f}_{\mathrm{g}}=7.72 \mathrm{~Hz}$ Getaran paksa dlekukan dengan cera memberiken genoguen peda bevo berupe fungesi hamonls gedangkan getaran bebes dlakulcan dengan cara memberlkan magukan berupa impot's pada $\mathbf{M}_{\mathbf{1}}$, $\mathrm{M}_{2}$ dan $\mathrm{M}_{\mathbf{3}}$

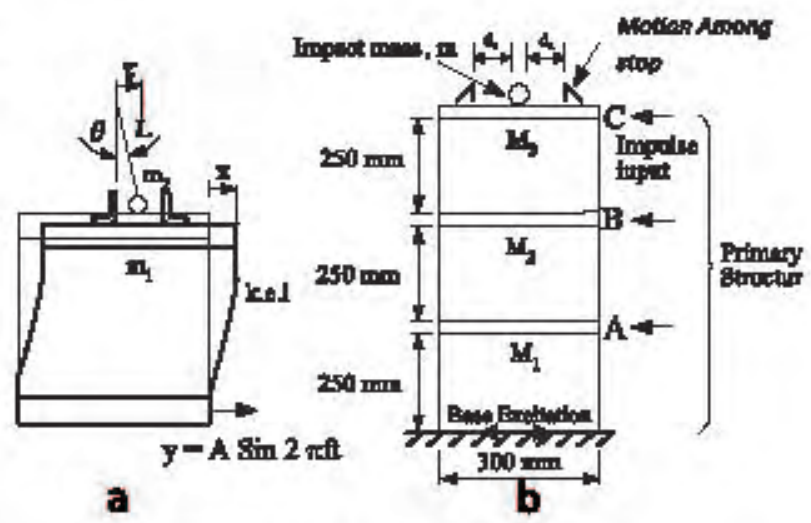

Gambar 3 (a) Model Eksperimental Ekwaro

(b) Model Eksoperimental Y. L
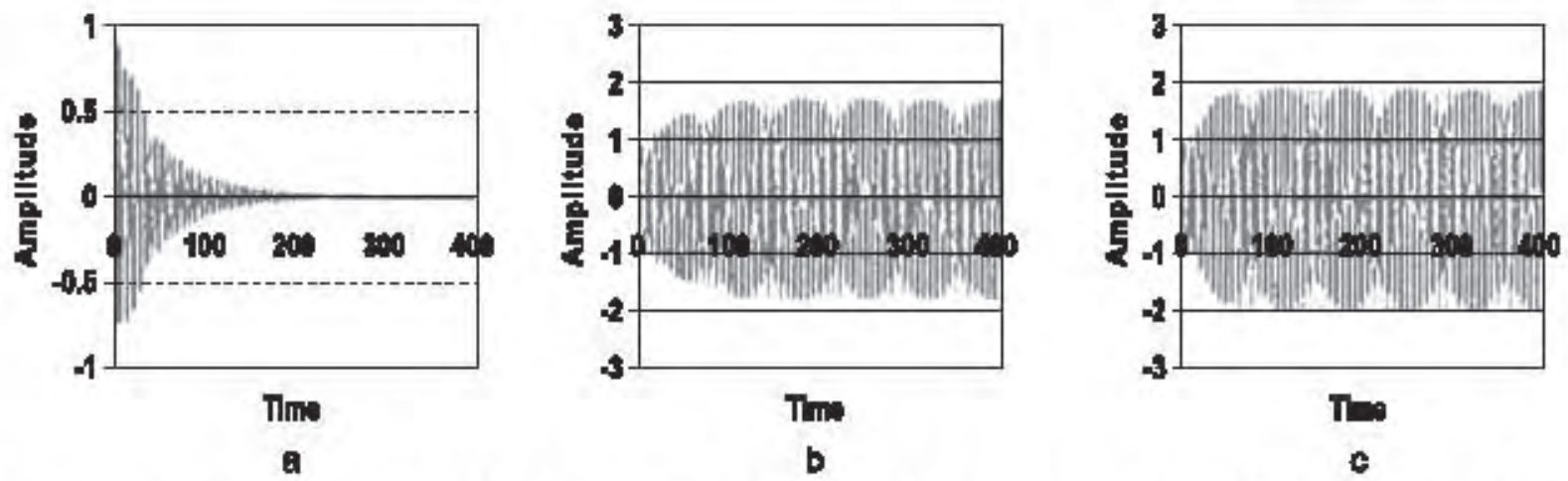

Gambar 2 Pengarnh nou linieritas $\&$ pede penedaman, $\beta=0.3, \delta=0.35, C=30$, (a) $\varepsilon=0.1$, (b) $\varepsilon=0.15$, (c) $\varepsilon=0.2$ 
Kedua nya mencatat hasil serupa yaitu parameter impact damper yang berpengaruh terhadap peredaman getaran shear building adalah mass ratio dan clearence ratio, baik pada kasus geraran bebas maupun getaran paksa. Semakin besar nilai mass ratio dan clearence ratio nya, semakin besar pula potensi dari impact damper dalam meredam getaran shear building. Kedua nya juga mencatat pada clearence ratio di atas harga optimum nya, sistem menjadi kontra-produktif. Yang unik adalah impact damper mampu meredam shear building pada frekuensi pribadi nya, hal yang tidak pernah terjadi pada sistem peredaman dinamis.

\section{Chatter Pada Mesin Perkakas}

\section{Mode Coupling}

Penomena SEV pada mesin perkakas dinamakan Chatter ditandai dengan bergetar nya pahat dan benda kerja selama proses pemesinan. Akibat yang ditimbulkan dari getaran ini adalah terjadi nya kekasaran pada permukaan benda kerja, keausan pahat dan konsumsi energi yang berlebihan (Tamás, 2004). Ada dua mekanisme pembentukan chatter yaitu mode coupling dan regererative circle (Ganguli, 2005 dan Gasparetto, 2001). Mode coupling merupakan getaran pahat dengan dua derajad kebebasan atau lebih dengan orientasi getar dan pase yang berbeda sedangkan phenomena regenerative circle terjadi pada process turning $\mathrm{dl}$ mana pahat memotong kekasaran permukaan yang dihasilkan oleh pemotongan sebelum nya.

Gaspareto et al. ( 2001) melaporkan phenomena mode coupling pada proses pemotongan kayu dengan menggunakan pahat jenis end mill. Tujuan penelitian ini adalah mencari parameter pemotongan yang menghasilkan chatter beserta solusi untuk menstabilkan getaran nya.

Model dari sistem ditunjukkan pada gambar $4 a$. Variasi gaya potong $\mathrm{F}$ akibat variabilitas parameter pemotongan (kekerasan benda kerja yang tidak homogen, luas pemotongan yang tidak konstan)

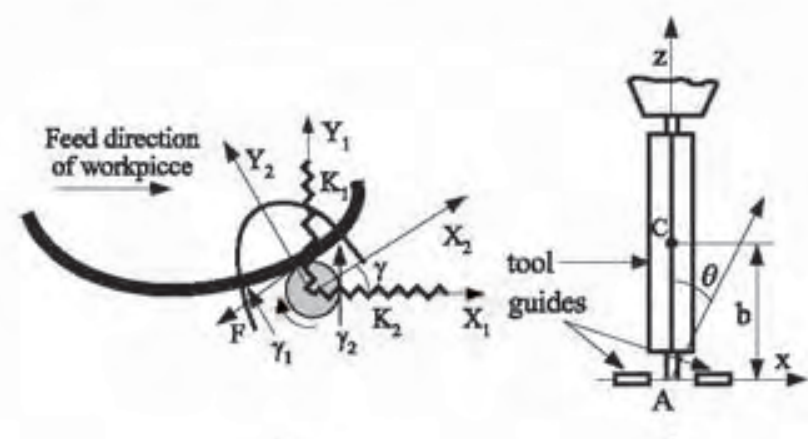

a

b

Gambar 4 (a) Pemodelan pemotongan pahat (end mill) ke benda kerja; (b) Model getar pahat dua derajad kebebasan memberikan trigger pada pahat untuk bergetar dalam arah $\mathrm{X}$ dan dalam arah $\mathrm{Y}$. Getaran pahat dimodelkan dalam sistem getar dua derajad kebebasan ditunjukkan pada gambar $4 \mathrm{~b}$. Dibuat konstante $\mathrm{k}$ yang besar nya tergantung dari bahan benda kerja, tebal pemotongan dan besar feөding serta $\gamma$ merupakan sudut antara arah maju pahat dengan garis singgung di titik kontak antara pahat dengan benda kerja (Gambar 4a). Gaspareto menghubungkan stabilitas dari getaran sistem dengan besar sudut $\gamma$ Persamaan gerak dari getaran pahat dinyatakan sebagai :

$$
\begin{aligned}
& {\left[\begin{array}{cc}
M_{x} & 0 \\
0 & M_{y}
\end{array}\right]\left\{\begin{array}{l}
\ddot{u}_{x} \\
\ddot{u}_{y}
\end{array}\right\}+\left[\begin{array}{cc}
K_{x} & 0 \\
0 & K_{y}
\end{array}\right]\left\{\begin{array}{l}
u_{x} \\
u_{y}
\end{array}\right\}=} \\
& {\left[\begin{array}{cc}
k \sin \gamma \cos \gamma & -k \cos ^{2} \gamma \\
k \sin ^{2} \gamma & -k \sin \gamma \cos \gamma
\end{array}\right]\left\{\begin{array}{l}
u_{x} \\
u_{y}
\end{array}\right\}}
\end{aligned}
$$

Persamaan 1 merupakan persamaan diferensial getaran bebas dua derajad kebebasan yang tidak terkopling dimana Persamaan karakteristik nya akan menghasilkan nilai $\gamma$ (Gambar 4a) yang merupakan batas stabilitas getar dari sistem yaitu $\gamma_{1}>\gamma>\gamma_{2}$.

Bila terjadi kondisi tidak stabil, Gaspareto mengajukan solusi sebagai berikut:

- Jika $\gamma>\gamma_{1}$ dan berdekatan dengan $\gamma_{1}$, maka mode coupling chatter dapat dihindari dengan memperbesar kekakuan dalam arah $Y$ - Bila $\gamma$ besar dan $\gamma<\gamma_{2}$, maka mode coupling chatter dapat dikurangi dengan memperbesar kekakuan dalam arah $\mathrm{X}$ atau dengan cara klasik yaitu dengan memberikan peredaman pada sistem.

\section{Regenerative Process}

Ganguli et al. (2005) melaporkan penomena chatter akibat regenerative process selama proses pemesinan. Eksperimental dilakukan pada hardware simulator berikut solusi guna menstabilkan

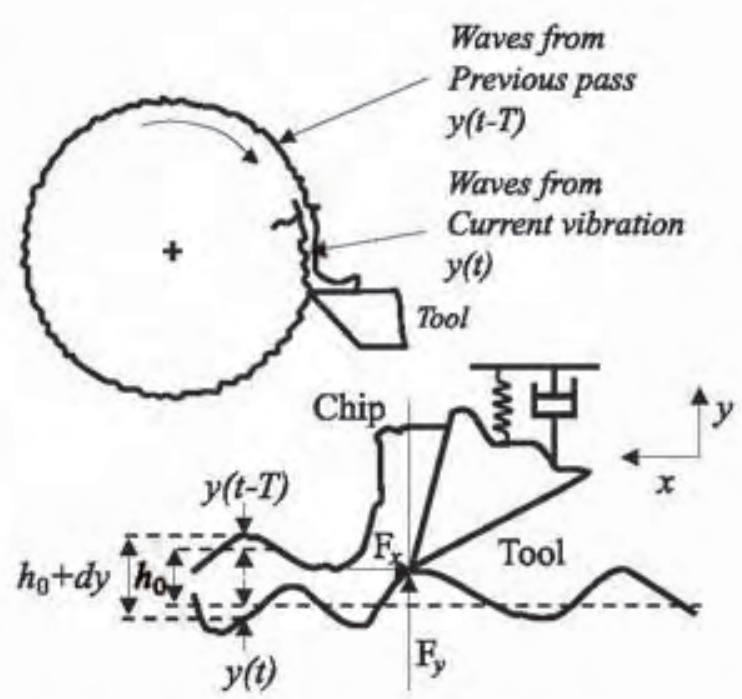

Gambar 5 Phenomena regenerative process 
getarannya.

Phenomene rogenerotivo procoses deri Ganguli dlthnjukkan pada Cambar 5 Keksarasan benda kerja yang tidak homogen membuat gaye potong $F$ tidak kontem sehingea pahst potong nya berpotar. Hal ini membuat permukaan hasll pemotongan bergelombang sehingga besear gaya potong berlkut nya lebih variatif. Prosess ini membuat pahat den benda kerja bergetar dan terjadllah phenomena chatter. Fungsl transfer darl akstem getar dllaporkan oleh Ganguli seperti terlahat pada persamaan (2)

Dimane

$$
\frac{h(s)}{h_{0}(s)}=\frac{1}{1+K_{f . .} G(s)\left(1-e^{s}\right)}
$$

$$
G(s)=\frac{y(s)}{F_{c}(s)}=\frac{1}{m s^{2}+c s+\hbar}
$$

Dengan $h(t)$ tebal pemotongan, $y(t)$ derajad kebebasen, ho adalah feeding, $a$ adalah tebal pemotonipen dan $\mathrm{K}_{\mathrm{r}}$ adalah peye potong spesink. Disinl $m$, $c$ dan $k$ adalah parameter getar dan $\mathrm{T}=60 / \mathrm{N}$ ( $\mathrm{N}$ adalah putaran apindel) sedangkan s edebah transtormass derl domaln wektu t ke domain laplace.

Gangull membuat peralatan slmulasl (Cambar 6) yong didasarkan atas persamatun (2) yeng tordiri atas beam (merepresentaslkan benda kerla), valce

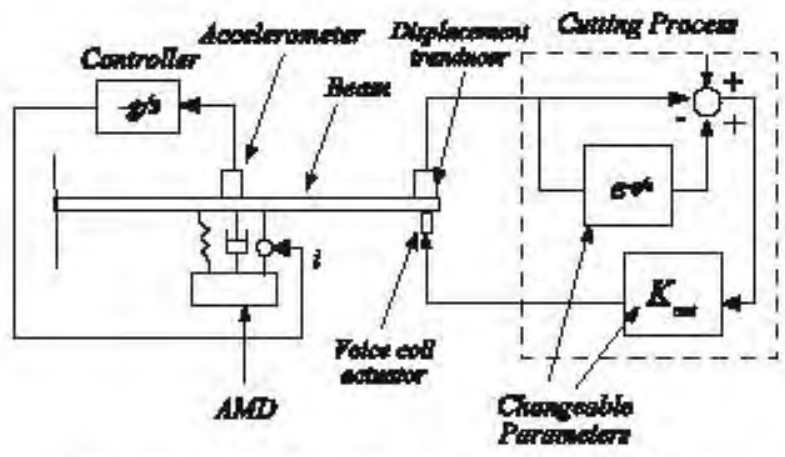

Gambar 6 SImulator beserta kontrol stabllttas

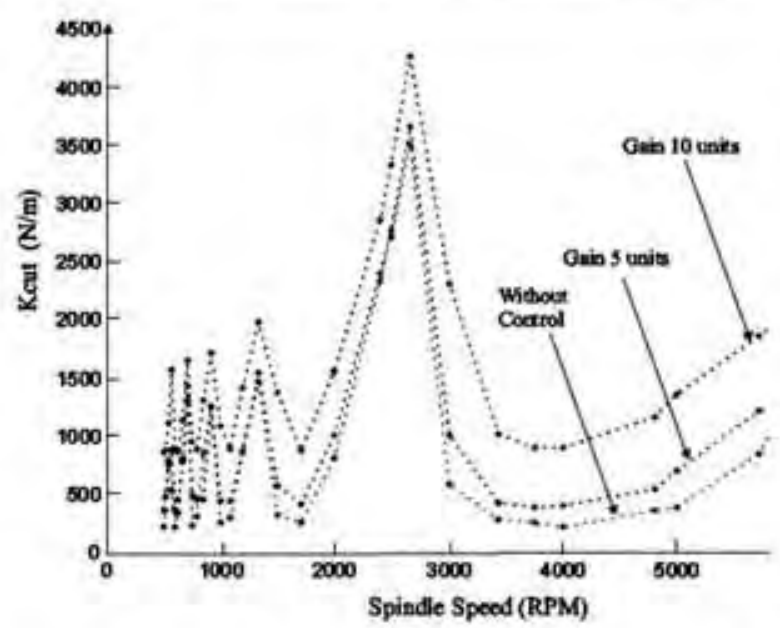

Gambar 7 Hessil simulagi (AMD den controller dlaktikkan) coll actusator yeng berfungsl untuk menggetarkan boum den displacemont tronducor guna mencelat getaran beem. Cotaran dari volos coll actuator didapat darl sinyal generator yang mendapat umpen ballk dari displacement trendiducer. Putaran poros dlaimulaskan sebagal vartabel T dan dlkombinasikan dengan varlas! $K_{a}=K_{1}$. a dlamat batas stabilltas getaran porot.

Hagl simukas dltunjukkan pada Gambar 7 untuk $g=0$. Daerah dlakas graflk menyatakan daerah tldak stabil. Dengan demikien perbaikan chatfer stabitity dlakukean dennan cara memperilues dearah dl bewah grafik. Untuk thu pada beam dlpasang Actwa Mass Demoer (AMD). Getaran dari boem ditangkap oleh accelerometer solenjut nya sinyal gotar nya dlbesarkan oleh confroller dengan memvarlasl kconstanke g. Hessi simulasi diturnjukkan pada Cambar 7 dengen verlest $=5$ den $p=10$. Torthat adamya perbalkan batas stahilltas dltandal dengan semakin tinggi nya limit atability bila AMD nya diaktifkan.

\section{Pengaruh SaV pada Kenyamanan Cperntor}

\section{Agrtowhurs Hechinary}

Kebanyakan mesin-mesin pertanlen beroperagl pade daveralh yang potontid monghatilken gotaren. Hal In berpengaryh pada kemyamanan dan kesehatan operator dan produktlvitas kerja darl glatem. Gengguan yang berpotensi dalam menggetarkan mesin pertanlan dlakdbatkean oleh ketldak-rataan pexmukasen tenah, varkasl beban gaya gekama mesin pertanian beroperesi (frekuersi rendah) oerta goteren pada mealn pengcorak (troluens tinggl). Cekaran yang berpengaruh terhadap kenyamanan operator gdaleh getaran dalem arah longhudingi, arah vartikal den arah sudut

Ketahanan operator dalam mengoperaslkan mesir-mesin pertanien tergantung peda percepatan getar serta frokuensi potar selama mesin tersebut beroperasl dan telah dbakukan sesal dengan ISO: 2631 / 1-1985 (Mehta ot af., 1997)

Peramoter dl atas dilgunakan odeh Mehta of of. (1997) guna menellt ketahanan operator dalam

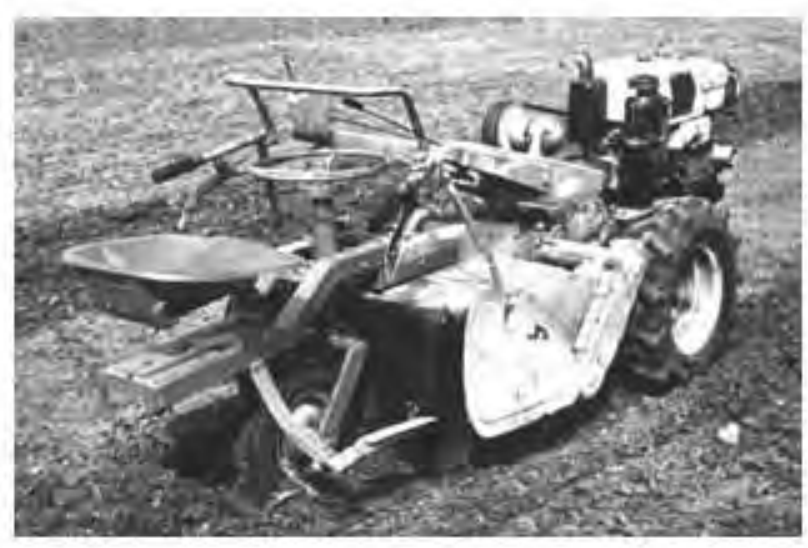

Gembar 8 Rotery Power Thtar kapecttes $7.5 \mathrm{~kW}$ 
mengoperasikan salah satu jenis Rotary Power-Tiller kapasitas 7.5 kW yang ada di India (Gambar 8). Penelitian dilakukan pada saat power tiller melaju pada tarmacadam road, farm road, untilled field dan pada Tilled field. Penelitian juga dilakukan saat power tiller dalam kondisi beroperasi pada Untilled field dan pada Tilled field.

Sebagai transducer digunakan accelerometer (dipasang dibawah tempat duduk operator) yang dapat mendeteksi sinyal getaran dalam arah longitudinal, arah vertikal dan arah sudut. Mehta mendapatkan hasil yaitu operator akan tahan selama 8 Jam dalam mengendaral Power-Tiller pada semua kondisi jalan sedangkan saat beroperasi, operator akan tahan mengoperasikan Power-Tiller selama 2.5 jam dalam kondisi rotatilling dan 4 jam dalam kondisi rotapuddling tanpa berhenti

Ride comfort dari traktor yang dikaitkan dengan posisi virtual hitch point (VHP) dari implement telah diteliti oleh Sakai ot al (1998). Posisi dari (VHP) disimulasikan oleh komputer dan hasil nya diferivikasi secara eksperimental. Model matematik dari penelitian Sakai berupa traktor berikut implement nya ditunjukkan pada Gambar 9. Roda traktor dimodelkan sebagai pegas linier $\mathbf{k}$ dan peredam viskus $\mathrm{c}$, gayagaya pemotongan tanah dalam arah vertical dan horizontal bekerja pada chisel

Persamaan gerak getaran sistem dalam koordinat rampak $q$ dalam tiga derajad kebebasan ditulis dalam bentuk matri ks sebagai berikut :

$$
[m]\{\ddot{q}\}+[c]\{\dot{q}\}+[k]\{q\}=\{f\}
$$

Guna simulasi, dipilih parameter getar yang sesuai dengan kondisi traktor seperti terlihat pada Tabel 2. Ada tiga kondisi yang disimulasikan yaitu pengaruh
Tabel 2 Parameter getar yang digunakan dalam simulasi

\begin{tabular}{llll}
\hline $\mathrm{C}_{1}=5500$ & {$[\mathrm{~N} /(\mathrm{m} / \mathrm{s})]$} & $\mathrm{l}_{0}=1.549$ & {$[\mathrm{~m}]$} \\
$\mathrm{C}_{2}=6690$ & {$[\mathrm{~N} /(\mathrm{m} / \mathrm{s})]$} & $\mathrm{l}_{1}=0.780$ & {$[\mathrm{~m}]$} \\
$\mathrm{C}_{3}=6400$ & {$[\mathrm{~N} /(\mathrm{m} / \mathrm{s})]$} & $\mathrm{l}_{2}=0.587$ & {$[\mathrm{~m}]$} \\
$\mathrm{H}_{0}=0.078$ & {$[\mathrm{~m}]$} & $\mathrm{M}=874$ & {$[\mathrm{~kg}]$} \\
$\mathrm{h}_{1}=0.586$ & {$[\mathrm{~m}]$} & $\mathrm{m}=149$ & {$[\mathrm{~kg}]$} \\
$\mathrm{J}_{6}=320$ & {$[\mathrm{~kg}-\mathrm{m}]$} & $\mu_{1}=0.12$ & \\
$\mathrm{~K}_{1}=304000$ & {$[\mathrm{~N} / \mathrm{m}]$} & $\mu_{2}=0.12$ & \\
$\mathrm{~K}_{2}=372000$ & {$[\mathrm{~N} / \mathrm{m}]$} & $\mu_{3}=0.15$ & \\
$\mathrm{k}_{3}=316000$ & {$[\mathrm{~N} / \mathrm{m}]$} & &
\end{tabular}

posisi virtual hitch point, posisi gaya pemotongan pada chisel dan posisi roda kontrol pada implement. Sakai menyimpulkan bahwa posisi virtual hitch point merupakan kondisi yang paling berpengaruh terhadap kenyamanan operator.

Hasil simulasi berupa contour line percepatan getar dalam arah vertikal di bawah tempat duduk operator ditunjukkan pada Gambar 10. Daerah yang diarsir menyatakan posisi VHP yang memberikan percepatan getar kurang dari $4 \mathrm{~m} / \mathrm{dt}^{2}$ yang merupakan kondisi terbaik dari operator selama mengoperasikan traktor

Selanjut nya hasil simulasi diuji secara eksperimental pada kondisi kecepatan traktor 0.23 $\mathrm{m} / \mathrm{dt}$ dan frekuensi shank $9.0 \mathrm{~Hz}$.. Hasil eksperimental dianalisis dengan menggunakan $1 / 3$ octave band method. Hasilnya adalah jika VHP nya berada dititik C, operator akan tahan mengoperasikan traktor selama 8 jam sedangkan di titik lain diluar daerah yang diarsir ketahanan operator dalam mengoperasikan traktor akan kurang dari 4 jam.

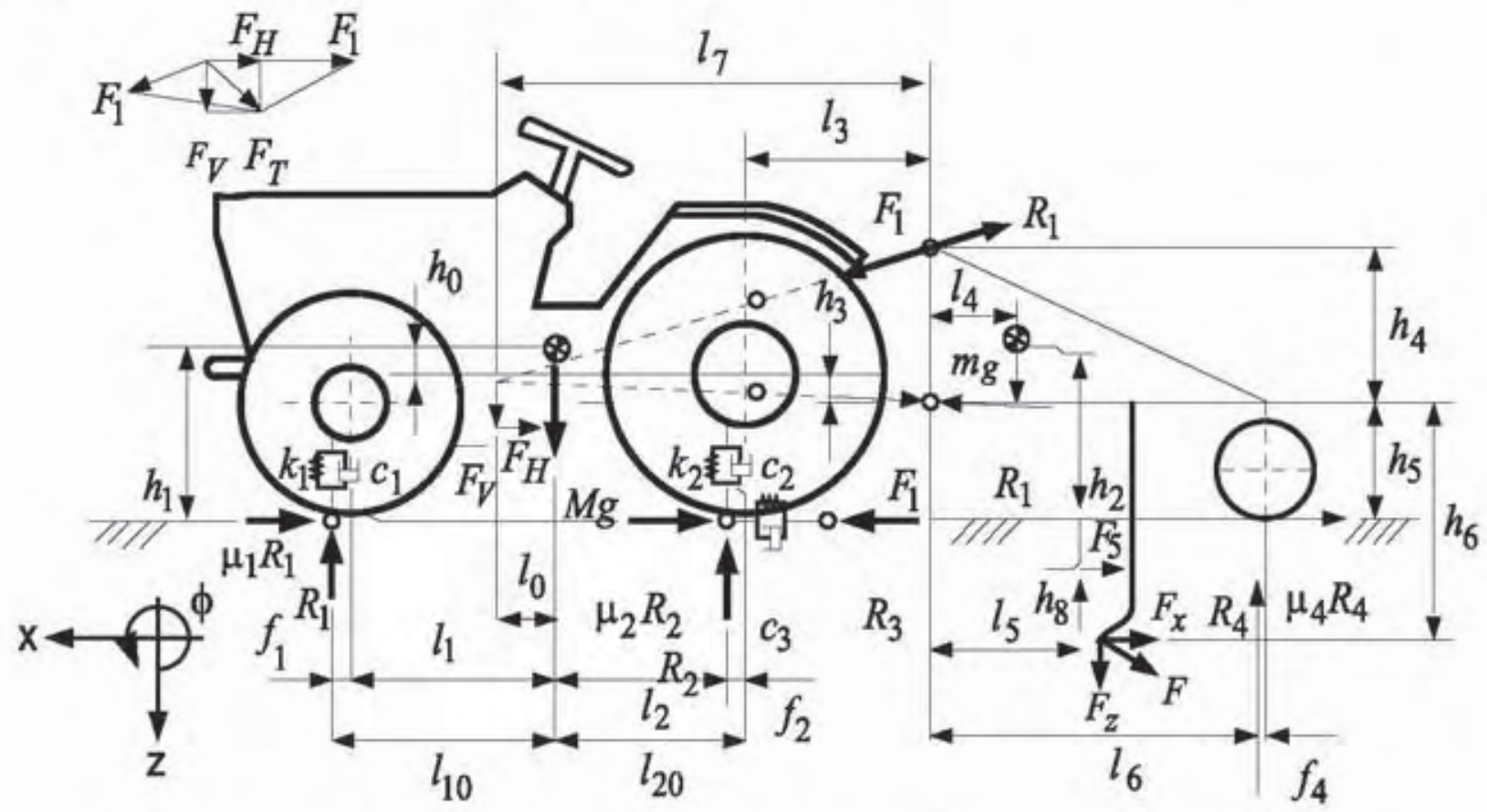

Gambar 9 Model matematik dari tractor-vibrating subsoller 


\section{Penomena Stick-Slip}

Penomena SEV lainnya yang akan di review adalah penomena stick-slip yang ditandai dengan lepas nya energi getar (yang terkumpul selama gerakan sistem) secara tiba-tiba, selanjutnya massa akan bergetar mengatasi hambatan baik yang berupa gesekan maupun yang berupa peredaman. Penomena stick-slip digambarkan oleh A. J. Mcmilan (1997) seperti terlihat pada Gambar 11 terdiri atas system getar SDOF dan konveyor. Pada awal nya, massa $\mathrm{m}$ bergerak mengikuti konveyor sehingga memberi energi regangan pada pegas $\mathbf{s}$, dan sesaat setelah terjadi keseimbangan energi, terjadllah penomena stick-slip

Respon dari massa m dinyatakan dalam diagram phase-plane (Gambar 12). Loop terluar menyatakan kondisi osilasi stick-slip sedangkan titik di dalam menyatakan kondisi steady-slip dengan kecepatan konstan $v_{b}$. Jika kondisi awal dari massa (dalam posisi $x$ dan kecepatan v) lebih dekat ke loop terluar, maka energi regangan pegas dan energi kinetik massa akan mampu mengatasi kerugian energi pada peredam sehingga gerakan massa $\mathrm{m}$ akan membesar, terjadilah osilasi stick-slip. Sebaliknya jika kondisi awal dari massa lebih dekat ke titik dalam, maka energi kinetik dari massa dan energi regangan pegas akan diredam oleh peredam sehingga terjadilah kondisi steady-slip.

Penomena stick-slip pada SEV banyak dijumpai pada mesin-mesin pertanian kusus nya pada bajak getar. Penomena ini terjadi jika batang pahat nya adalah elastis atau pada batang pahat nya dipasang

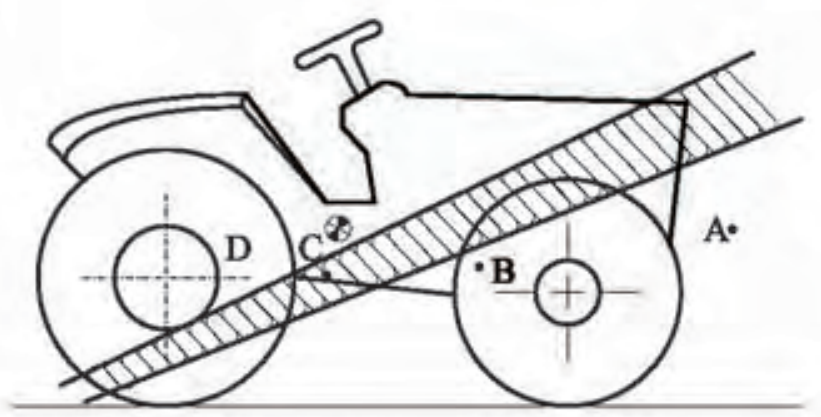

Gambar 10 Cortour line hasil simulasi dengan komputer

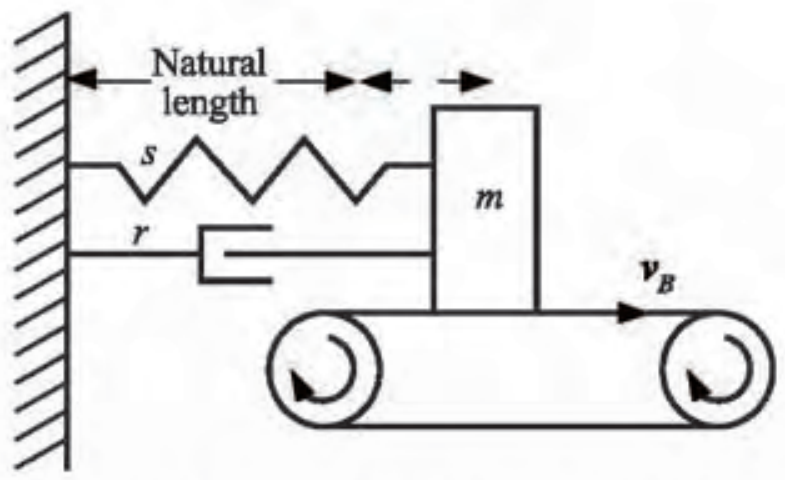

Gambar 11 Penomena Stick-Slip dari A. J. McMilan pegas. Pada saat pahat bergerak maju, tahanan tanah membuat batang pahat atau bagian elastis dari batang pahat terdefleksi sehingga energi nya disimpan dalam bentuk energi potensial. Pada saat tanah terbongkar, tahanan tanah menjadi jauh berkurang selanjutnya batang pahat berosilasi sesuai dengan penomena stick-slip. Tujuan dari sistem inl adalah untuk mengurangi tahanan tanah sehingga gaya tarik pada implement menjadi rendah.

Qiu Lichung dan L Baufa (2000) membuat bajak getar guna menurunkan tahanan tanah dengan menggunakan metode self excited vibration. Skema peralatan ditunjukkan pada Gambar 13. Pegas elastis dipasang antara traktor dengan implement menggantikan fungsi upper link. Sistem bekerja pada kedalaman antara $26 \mathrm{~cm}$ hingga $29 \mathrm{~cm}$. Dibandingkan dengan bajak biasa (pegas diganti dengan batang kaku), Qiu Lichung mencatat penurunan tahanan tanah sekitar $10.8 \%$ dan penurunan cone index sekitar $13 \%$.

R. Bemstsen et al (2006) melakukan penelitian tentang draft yang dibutuhkan guna membongkar kepadatan tanah dengan menggunakan rigid tines dan flexible tines. Penelitian dilakukan pada loam soll pada dua kondisi yang berbeda yaitu pada tilled soil dan pada no-tidled soil serta pada dua kondisi kecepatan yaitu $1 \mathrm{~m} / \mathrm{s}$ dan $2 \mathrm{~m} / \mathrm{s}$ Kedalaman pemotongan dilakukan pada $0.06 \mathrm{~m}$ dan $0.12 \mathrm{~m}$.

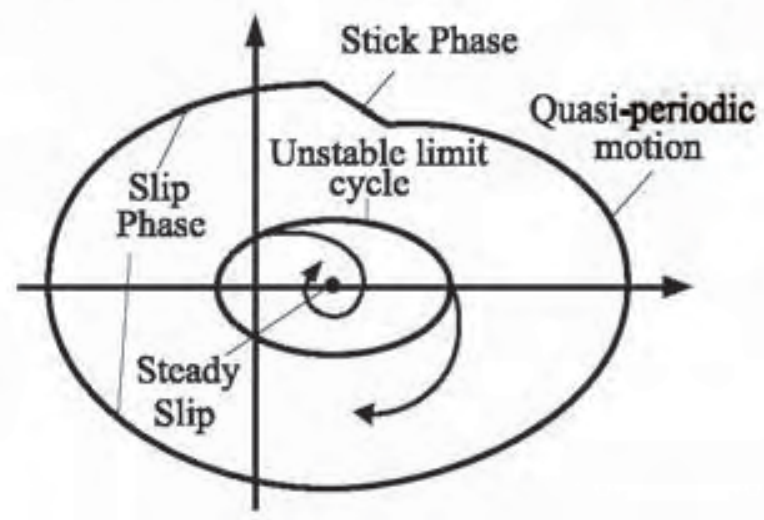

Gambar 12 Diagram phase plane dari respon massa $\mathrm{m}$

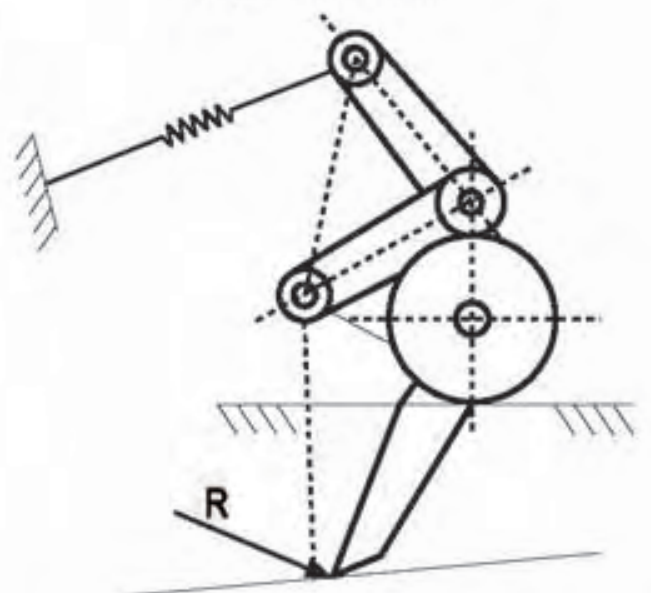

Gambar 13 Bajak getar dari Qiu Lichung dan Li Baufa 
Tabel 3 Kekakuan dari masing-masing Tines

Force per $\mathrm{cm}$ tire deflection $\left(\mathrm{N} \mathrm{cm}^{-1}\right)$ of the flexible tines

\begin{tabular}{lccccc}
\hline Soll state & \multicolumn{2}{c}{ Fleksible straight tines } & & \multicolumn{2}{c}{ Flexible S-tires } \\
\cline { 2 - 3 } \cline { 5 - 6 } & FS1 & FS2 & & S45 & S34 \\
\hline No-tilled soil & 38 & 30 & & 48 & 40 \\
Tilled soil & 30 & 8 & & 48 & 40 \\
\hline
\end{tabular}

Dalam penelitian nya, Bernstsen menggunakan tiga jenis tines (Gambar 14) yaitu rigid tine (R), Flexible straight tines (FS1 dan FS2) dan Flexible $S$ tines ( S45 dan S34).

Data kekakuan dari masing-masing tines ditunjukkan pada Tabel 3. Flexible stright tine (FS2) mempunyai kekakuan yang paling lemah pada tilted soil dan pada no-tilled soil yaitu masing-masing 30 $\mathrm{N} / \mathrm{cm}$ dan $8 \mathrm{~N} / \mathrm{cm}$.

Jika dioperasikan pada no-tilled soil, Bernstsen mencatat penurunan gaya potong tanah pada flexible straight tines dan flexible $\mathrm{S}$ tines berturut turut sebesar sebesar $20 \%$ dan $28 \%$ jika dibandingkan dengan gaya potong tanah yang diperlukan oleh rigid tine (Gambar 15). Pada tilled soll, terjadi hal sebalik nya yaitu rigid tine memberikan draft paling rendah kecuali pada FS2, yang karena fleksibilitas nya memberikan draft yang lebih rendah dibandingkan dengan draft untuk rigid tine

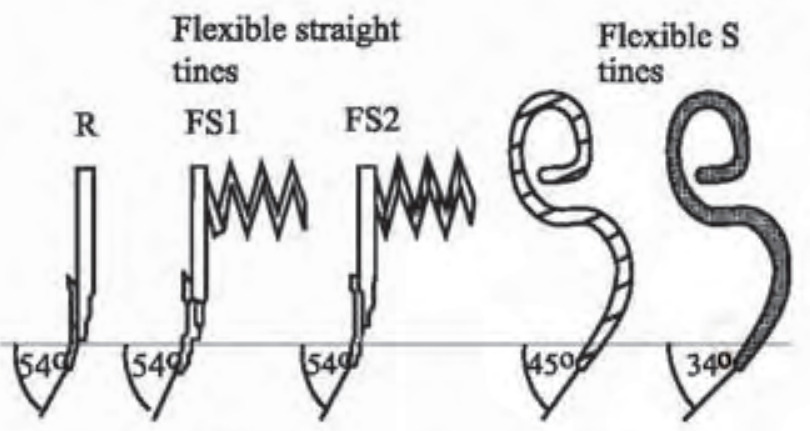

Gambar 14 Jenis Tines yang digunakan oleh

Bernstsen et al.

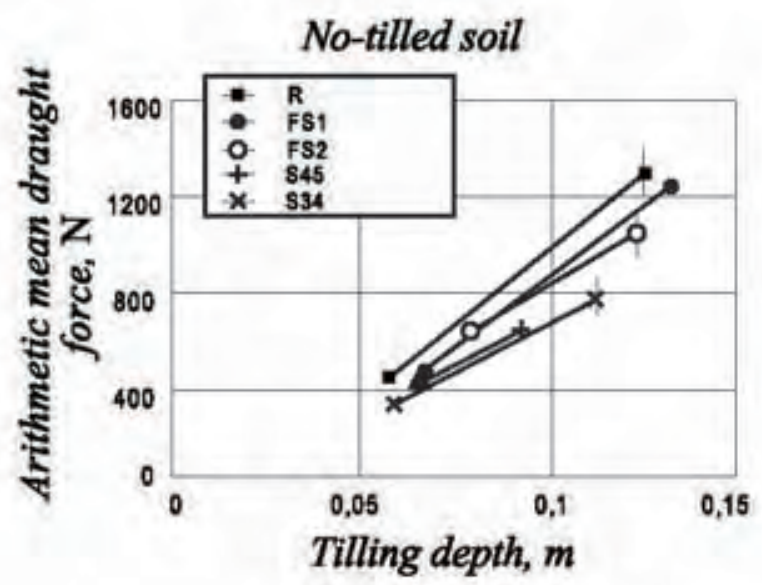

Hasil-hasil yang didapat dianalisis lebih lanjut oleh Bernstsen dengan menggunakan two-level model (kombinasi antara kecepatan dengan kedalaman potong). Didapat hasil yaitu peak force (gaya maks. Saat pahat bergerak memotong) pada flexible tines mempunyai besar yang lebih tinggi jika dibandingkan peak force pada rigid tine, sedangkan 7 rough force nya (gaya min. Saat pahat bergerak mundur) pada flexible tines mempunyai besar yang lebih rendah jika dibandingkan 7 rough force pada rigid tine. Kendati demikian, besar rata-rata dari gaya pada flexible tines tercatat lebih rendah jika dibandingkan besar rata-rata dari gaya pada rigid tine

\section{Kesimpulan}

Telah dilakukan review dari journal yang relevan tentang penomena Self Excited Vibartion pada beberapa model fisis dan penerapan nya pada bidang yang berbeda. Model fisis dan bidang yang dimaksud adalah penomena Impact Damper pada shear building, penomena chatter pada mesin perkakas, penomena ride confort pada agricultural machinery dan penomena stick-slip pada bajak getar. Hal yang menarik adalah:

- Pengaruh paling dominan dalam peredaman getaran shear building pada kasus impact damper adalah mass ratio dan clearance ratio.

- Penomena Chatter pada mesin perkakas dapat digeneralisasikan melalui proses regeneratif circle dan melalui penomena mode coupling

- Penempatan virtual hitch point yang tepat pada traktor-implemen dapat menaikan ketahanan operator dalam mengoperasikan traktor.

- Penomena stick-slip pada bajak getar mampu menurunkan draft yang diperlukan untuk membongkar kepadatan tanah, dan besar penurunan nya tergantung dari elastisitas batang pahat serta kondisi awal tanah

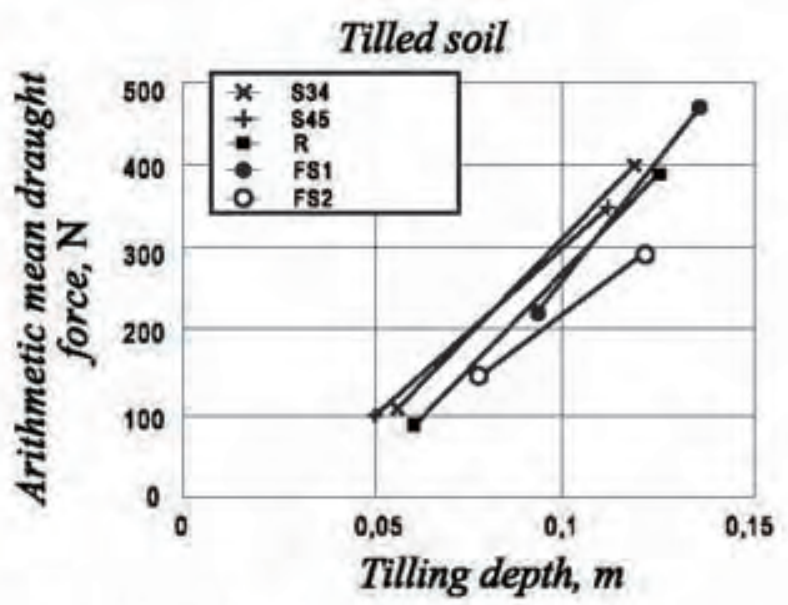

Gambar 15 Gaya potong tanah rata-rata sebagai fungsi dari kedalaman potong a. Pada No-tilled soil, b. Pada tilled soil 


\section{Daftar Pustaka}

Asfar. K. R and Akour N. S, 2005, Optimazion Analysis of Impact Viscous Damper for Controlling SelfExcited Vibration, Journal of Vibration and Contril, 11(1), 103-120

Berntsen R., Berre B., Torp T., Aasen H., 2006, Tine force established by a two level model and the draught requirement of rigid and flexible tines, Soil and Tillage Rearch, 90, 230-241

Ekwaro s. And Desen C. I., 2001, Experimental study on Impact Vibration Absorber, Jornal of Vibration and Control,7(4), 475-493

Ganguli A, Deraemaeker A, Horodinca M, Preumont A., 2005,Active damping of chatter in machine tools - Demonstration with a "Hardware in the Loop" simulator,Journal of Systems and Control Engineering, Proceedings of the Institution of Mechanical Engineers, vol 219, No15, p. 359-369

Gasparetto A., 2001,Eigenvalue Analysis of ModeCoupling for Machine-Tool Stabilization Journal of Vibration and Contriol,7(2), 181-198
Li L. And Darby P.A., 2006, Experiments on the Effect of an Impact Damper on a Multi Degree-ofFreedom System, Jornal of Vibration and Contriol,12(1), 445-464

Mcmillan J.A., 1997, a Non-Linear Friction Model for Self-Excited Vibrations, Journal of Sound and Vibration, 194, 212-224

Mehta R. C., Twari S. P., Varshney C. A., 1997, Ride Vibrations on a $7.5 \mathrm{kw}$ Rotary Power Tiller, Joumal of Agricultural Engineering Research, 66, 169176.

Qiu Lichung and Li Baufa, 2000, Experimental Study on the Self-Excited Vibration subsoilerfor Reducing Draft Force, Transaction of the Chinese Society of Agricultural Engineering, Vol.16 no. 6 p 72-76

Sakal K, Terao H and Nambu, 1988, Sakai K, Terao $\mathrm{H}$ and Nambu, 1988, The Dynamics Behaviour of a Tractor-Vibrating Subsoiler System and the Effect of the Virtual Hitch Point, Journal of Terramechanics, Vol. 25, pp. 241-247 Tamás Kalmár-Nagy and Francis C. Moon, 2004, Mode-Coupled Regenerative Machine Tool Vibrations, Nonlinear dynamics of Production System, pp 129-149 